\title{
NITRATE AND AMMONIUM IN SOIL SOLUTION IN TOBACCO MANAGEMENT SYSTEMS ${ }^{(1)}$
}

\author{
Douglas Rodrigo Kaiser ${ }^{(2)}$, Dalvan José Reinert ${ }^{(3)}$, José Miguel \\ Reichert $^{(3)}$, Carlos Arnoldo Streck ${ }^{(4)} \&$ André Pellegrini ${ }^{(2)}$
}

\begin{abstract}
SUMMARY
Tobacco farmers of southern Brazil use high levels of fertilizers, without considering soil and environmental attributes, posing great risk to water resources degradation. The objective of this study was to monitor nitrate and ammonium concentrations in the soil solution of an Entisol in and below the root zone of tobacco under conventional tillage (CT), minimum tillage (MT) and no-tillage (NT). The study was conducted in the small-watershed Arroio Lino, in Agudo, State of Rio Grande do Sul, Brazil. A base fertilization of $850 \mathrm{~kg} \mathrm{ha}^{-1} \mathrm{of}$ 10-18-24 and topdressing of $400 \mathrm{~kg} \mathrm{ha}^{-1}$ of 14-0-14 NPK fertilizer were applied. The soil solution was sampled during the crop cycle with a tension lysimeter equipped with a porous ceramic cup. Ammonium and nitrate concentrations were analyzed by the distillation and titration method. Nitrate concentrations, ranging from 8 to $226 \mathrm{mg} \mathrm{L}^{-1}$, were highest after initial fertilization and decreased during the crop cycle. The average nitrate $\left(\mathrm{N}-\mathrm{NO}_{3}^{-}\right)$concentration in the root zone was 75 in NT, 95 in MT, and $49 \mathrm{mg} \mathrm{L}^{-1}$ in CT. Below the root zone, the average nitrate concentration was 58 under NT, 108 under MT and $36 \mathrm{mg} \mathrm{L}^{-1}$ under CT. The nitrate and ammonium concentrations did not differ significantly in the management systems. However, the nitrate concentrations measured represent a contamination risk to groundwater of the watershed. The ammonium concentration $\left(\mathrm{N}_{-} \mathrm{NH}_{4}{ }^{+}\right)$decreased over time in all management systems, possibly as a result of the nitrification process and root uptake of part of the ammonium by the growing plants.
\end{abstract}

Index terms: nitrate leaching, agricultural watershed, water contamination, tension lysimeter.

\footnotetext{
(1) Part of the Master's dissertation of the first author. Research undertaken with resources from the CNPq and Fapergs. Received for publication in January 2009 and aproved in January 2010.

(2) Doctoral candidate in Soil Science. UFSM. CAPES Scholarship holder. E-mail: kaiser@mail.ufsm.br; andre.pellegrini@yahoo.com.br

(3) Full Professor of the Soil Department, Rural Sciences Center, Universidade Federal de Santa Maria (Federal University of Santa Maria) - UFSM. University Campus. CEP 97106-900. Santa Maria (RS) Brazil. E-mails: dalvan@ccr.ufsm.br; reichert@smail.ufsm.br

(4) Professor of the Instituto Federal do Rio Grande do Sul. Soil Science from UFSM. streckenator@gmail.com
} 


\title{
RESUMO: NITRATO E AMÔNIO NA SOLUÇÃO DO SOLO EM SISTEMAS DE MANEJO PARA CULTURA DO FUMO
}

\begin{abstract}
Os fumicultores do sul do Brasil seguem pacotes tecnológicos que impõem o uso de altas doses de fertilizantes, sem considerar os atributos do solo e do ambiente, representando grande risco para a degradação dos recursos hídricos. O objetivo deste trabalho foi monitorar as concentrações de nitrato e de amônio na solução do solo da região do sistema radicular e abaixo deste, em Neossolo Litólico cultivado com fumo sob preparo convencional (PC), cultivo mínimo (CM) e plantio direto (PD). O estudo foi conduzido na microbacia hidrográfica do Arroio Lino, localizada no município de Agudo - RS. A adubação de base foi de $850 \mathrm{~kg} \mathrm{ha}^{-1} \mathrm{de}$ 10-18-24, e a adubação de cobertura, $400 \mathrm{~kg} \mathrm{ha}^{-1}$ de 14-0-14. A coleta da solução do solo foi com lisímetros de tensão durante o ciclo da cultura. A concentração de amônio e de nitrato foi analisada pelo método da destilação e titulação. As concentrações de nitrato, que variaram de 8 a $226 \mathrm{mg} \mathrm{L}^{-1}$, foram maiores após a adubação de base e decresceram ao longo do ciclo. As concentrações médias de nitrato $\left(\mathrm{N}-\mathrm{NO}_{3}{ }^{-}\right)$na zona radicular foram de 75 no $\mathrm{PD}, 95$ no $\mathrm{CM}$ e $49 \mathrm{mg} \mathrm{L}^{-1}$ no PC. Abaixo das raízes, as concentrações médias de nitrato foram de 58 no $P D$, 108 no CMe $36 \mathrm{mg} \mathrm{L}^{-1-}$ no PC. Não houve diferença estatística significativa na concentração de nitrato e amônio nos sistemas de manejo. Entretanto, as concentrações de nitrato encontrados representam um risco potencial para contaminação da água subsuperficial das fontes da mibrobacia em estudo. A concentração de amônio $\left(\mathrm{N}-\mathrm{NH}_{4}{ }^{+}\right)$decresceu no tempo em todos os sistemas de manejo. Essa redução pode ter decorrido do processo de nitrificação e da absorção de parte do amônio pelas raizes das plantas em crescimento.
\end{abstract}

Termos de indexação: lixiviação de nitrato, bacia hidrográfica agrícola, contaminação da água, lisimetro de tensão.

\section{INTRODUCTION}

The States of Southern Brazil account for $96 \%$ of the nation's tobacco production and the main production regions are found on basaltic slopes and crystalline shield rocks (SCP, 2003). The soils of extensive areas of these regions are pedogenetically young and little suited for agriculture of annual crops, mainly due to the steep slopes and rocky nature of the landscape (Streck et al., 2008). Many rivers flow from these areas, form small watersheds, and are important for groundwater recharge (Merten \& Minella, 2002).

Incompatible agricultural practices with the land use capability of these regions and the application of high fertilizer and pesticide rates make tobacco cultivation an activity with a high contamination risk for water resources in watersheds. These factors also result in a rapid decline of the productive capacity of the soil (Minella et al., 2007) and local water quality (Gonçalves, 2003; Pellegrini, 2005; Becker et al., 2009).

Nitrogen and K are the nutrients most demanded by tobacco for high productivity and quality. Nitrogen is, at the same time, the most limiting nutrient to yield increase (McCants \& Woltz, 1967) and may contaminate groundwater when leached. In tobacco cultivation, sodium nitrate as topdressing fertilizer is used as a source of $\mathrm{N}$ and $\mathrm{K}$, due to the absence of chlorine and ammonium which, when taken up in excess, reduces tobacco combustion, affecting the cigarette quality (McCants \& Woltz, 1967). In addition, high ammonium concentrations reduce $\mathrm{K}$ uptake by tobacco plants (Scherer et al., 1984).

Tobacco has a root system concentrated near the soil surface (Pellegrini, 2006) with low nutrient uptake efficiency (Sifola \& Postiglione, 2003). Under low nitrate availability, the plant root system is stimulated to branch (Zhang et al., 1995), reducing the growth and development of the above-ground part and affecting leaf production. Consequently, after periods of frequent rains, supplemental applications of $\mathrm{N}$ topdressing are necessary to compensate nitrate losses (Whitty \& Gallaher, 1995). Otherwise, the uptake of other nutrients is less efficient, leading to reduced plant growth and development (McCants \& Woltz, 1967).

Agriculture is known as a diffuse source of contamination (Rheinheimer, 2003) and nitrate leaching through the soil profile is one of the main problems of water quality (Grignani \& Zavattaro, 2000; Rao \& Puttanna, 2000). Nitrate movement is favored by its high solubility and the low adsorption energy of the $\mathrm{NO}_{3}$ - anion with soil particles, especially in soils with predominantly negative charges (Alcântara \& Camargo, 2005). In tobacco-producing regions, most soils are little developed, due to the steep slopes of the areas and the low weathering degree. The Fe oxide content is low and the presence of positive charges is therefore not very frequent (Dalmolin et al., 2004), which makes the nitrate mobile and connects its movement directly with the soil water flow.

The nitrate load in surface water is a function of the volume transported and of the nitrate 
concentration in water. In periods of high precipitation, the soil remains saturated or near saturation for a longer time, favoring water flow in the soil and allowing a considerable part of the water to drain below the root zone, inaccessible to plants (Randall \& Mulla, 2001), recharging the groundwater. In shallow soils, saturation may be reached more rapidly during precipitation, which increases runoff and also increases saturated flow in the soil. In addition, the stoniness of the soils in these areas can increase soil water infiltration (Mandal et al., 2005) and favor water and nutrient losses by leaching. The magnitude of nutrient leaching is given by nutrient availability in the surface horizon and by the excess of rainfall over evapotranspiration (Paravasivam et al., 2000).

Nitrate concentrations above $10 \mathrm{mg} \mathrm{L}^{-1}\left(\mathrm{~N}-\mathrm{NO}_{3}^{-}\right)$ in drinking water pose serious risks to human health (Addiscott \& Benjamim, 2004). The nitrate concentration in the soil solution below the root zone has been suggested as a reliable indicator of the potential for groundwater contamination (Webster et al., 1993; Grignani \& Zavattaro, 2000).

The quantification of nitrate concentrations below the tobacco root zone is an important tool in the evaluation of the potential for water contamination of soil management systems and can contribute to soil use planning in watersheds. Thus, the objective of this study was to evaluate nitrate and ammonium concentrations in the soil solution in and below the root zone under different tobacco management systems.

\section{MATERIAL AND METHODS}

The study was conducted in the watershed Arroio Lino, in Agudo, Rio Grande do Sul, Brazil. The landscape of the small-watershed is very hilly to steep. Chernossolos (Mollisols in Soil Taxonomy) predominate, but Neossolos (Entisols in Soil Toxomany) are found on steeper slopes (Dalmolin et al., 2004). The watershed has an area of 480 ha comprising 36 farms properties (average area $10 \mathrm{ha}$ ) that depend economically on tobacco (Gonçalves, 2003).

The climate in the region is humid subtropical (Cfa type), according to the Köppen classification, with an average temperature of more than $22^{\circ} \mathrm{C}$ in the hottest and between -3 and $18{ }^{\circ} \mathrm{C}$ in the coldest month. Rains are usually well distributed, ranging from 1,300 to $1,800 \mathrm{~mm}$ year $^{-1}$, but concentrated mostly in May and June (Moreno, 1961).

The experimental area had been under tobacco cultivation for 8 years. Minimum tillage was the predominant soil management used for tobacco. After tobacco, maize was generally planted in the summer and oat in the winter. The soil in the area is an Neossolo Litólico (Embrapa, 1999). The predominant parent material is basaltic rock of the "Serra Geral" Formation, but there are also sandstone and siltstone in less quantity (Dalmolin et al., 2004). The average slope of the experimental units was near 0.23 and $0.02 \mathrm{~m} \mathrm{~m}^{-1}$ in the plant rows (ridge). The mean values of the granulometric composition of this soil were evaluated in the horizons Ap and A1 (Table 1). No C horizon or saprolite was observed below the A1 horizon, but only lithic contact.

The experimental design in randomized blocks with three replications consisted of the following management systems: conventional tillage (CT), minimum tillage (MT) and no-tillage (NT), evaluated in $10 \times 15$ m plots. Conventional tillage (CT) was done by plowing and disking over an area maintained fallow in the winter and later preparation of the ridge for the incorporation of base fertilization and planting of tobacco seedlings. The minimum tillage system was implanted over oat stubble. In the winter, the soil of these plots had been plowed and disked and oat was sown. Before transplanting tobacco, the area was treated with herbicide and a ridge was prepared for incorporation of the base fertilization and planting of the seedlings. The soil was prepared with a moldboard plow and a spike harrow with a triangular frame, pulled by draught animals. The farm equipment and soil management were the most commonly used by local farmers (Pellegrini, 2006). No-tillage was implanted over oat stubble of winter oat, on plowed and disked soil. Base fertilization in NT was applied in a small furrow (0.1 $\mathrm{m}$ depth), opened with a narrow moldboard plow. After application in the furrow, the fertilizer was incorporated by opening a new furrow alongside the first. The tobacco seedlings were also planted on top of this furrow.

Soil fertilization for tobacco was based on the recommendation of tobacco industries, that is $850 \mathrm{~kg} \mathrm{ha}{ }^{1}$ of NPK fertilizer 10-18-20 at planting and $400 \mathrm{~kg} \mathrm{ha} \mathrm{ha}^{-1}$ of sodium nitrate (14-0-14) in topdressing

Table 1. Granulometric composition of the Entisol in the Ap and A1 horizons

\begin{tabular}{ccccccc}
\hline Horizon & Layer & Stone & Gravel & Sand & Silt \\
\hline & $\mathrm{m}$ & & & $\mathrm{g} \mathrm{kg}^{-1}-$ & 490 & 405 \\
Ap & $0-0.2$ & 150 & 134 & 425 & 417 \\
\hline
\end{tabular}

Stones (> $20 \mathrm{~mm})$; gravel $(2-20 \mathrm{~mm})$; sand $(2-0.05 \mathrm{~mm})$; silt $(0.05-0.002 \mathrm{~mm})$ and clay $(<0.002 \mathrm{~mm})$. 
40 and 68 days after transplanting. About $200 \mathrm{~kg} \mathrm{ha}^{-1}$ was applied each time.

Tobacco seedlings were transplanted on December 9,2004 , with a spacing of $0.5 \mathrm{~m}$ between plants and $1.2 \mathrm{~m}$ between rows. Topdressing fertilization was applied with a seeder, so that the fertilizer was applied near the plants and at depths of 0.05 to $0.10 \mathrm{~m}$. Under CT and MT, the fertilizer was incorporated to a depth of $0.10 \mathrm{~m}$ with a moldboard plow after the application of topdressing fertilization, while under NT the soil was not tilled.

After tobacco harvest, 140 days after transplanting (DAT), corn was sown without soil tillage, starter fertilization or topdressing, in order to take advantage of exploit the remaining nutrients from previous application.

For sampling of the soil solution, suction lysimeters equipped with porous ceramic cups at (www.ictinternational.com.au/What-Lysimeter.htm) were installed, depths of 0.15 and $0.30 \mathrm{~m}$. The ceramic cups (diameter $0.061 \mathrm{~m}$ and height $0.065 \mathrm{~m}$ ) were connected to PVC pipes (diameter $0.05 \mathrm{~cm}$ and height 0.18 or $0.40 \mathrm{~m}$ ). The tobacco root system is most concentrated at $0.15 \mathrm{~m}$ (Pellegrini, 2006) and the horizon A1 of the soil of the experimental area is at a depth of $0.40 \mathrm{~m}$. Two soil solution extractors were installed in each plot. Orifices were opened with a Dutch auger, to insert the lysimeters, and the remaining space was filled with soil for a better soilcup contact. Afterwards, a layer of bentonite spread over the layer of compacted soil for better sealing and to avoid a lateral flow between the soil and the lysimeter wall.

To extract the soil solution after the rains that occurred during the crop cycle, a suction of $50 \mathrm{kPa}$ was applied in each lysimeter with a manual vacuum pump. In the period between 40 and 130 days after transplanting, the soil solution was not sampled, despite some high-intensity rains, due to the difficulty of reaching the watershed and because some rains were very localized. The soil solution was sampled with the lysimeters three days after tension application. By this method, it was possible to collect the solution in moisture conditions near field capacity and the small diameter of the cup pores prevented the entrance of coarse particles into the solution (Hendershot \& Courchesne, 1991).

The solution samples were stored in $50 \mathrm{~mL}$ glass vials, previously washed in cleaning solution $\left(0.0125 \mathrm{~mol} \mathrm{~L}^{-1} \mathrm{HCl}\right)$ and dried in a laboratory oven at $105{ }^{\circ} \mathrm{C}$ for $24 \mathrm{~h}$. Between samplings, the vacuum pump tubes were cleaned with cleaning solution and distilled water to avoid contamination of the soil solution samples. The vials containing the solution samples were stored in polystyrene boxes and maintained under refrigeration until analysis. The nitrogen content was determined by the distillation method with a semi-micro Kjeldahl procedure (Tedesco et al., 1995).

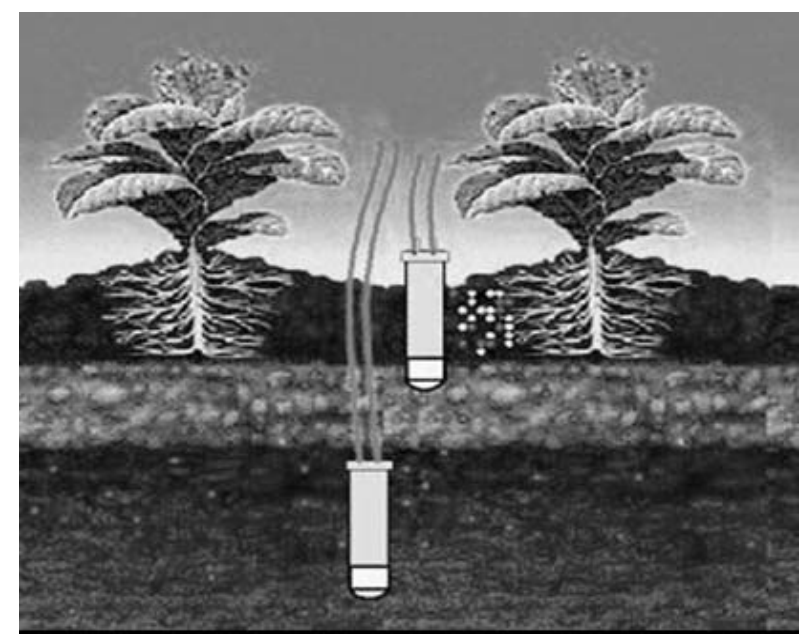

Figure 1. Scheme of the tension lysimeters equipped with porous cups installed in and below the tobacco root zone.

The amount of infiltrated and runoff water of each management system was monitored in small runoff plots $(1 \times 1.2 \mathrm{~m})$ equipped with runoff collectors. Infiltration amount is the difference between rainfall and runoff volumes. Rainfall data were obtained from an automatic weather station installed in the center of the microwatershed.

The data were subjected to analysis of variance and the means compared by the LSD test at $5 \%$. When sufficient solution sampling replications were not obtained (three observations) for statistical analysis, only the value observed in the treatment was presented.

\section{RESULTS AND DISCUSSION}

Rainfall was most frequent soon after transplanting tobacco (Figure 2). The soil retains a high water content in periods of greater rainfall and consequently, fertilizer solubilization, water flow and nitrate leaching to positions below the tobacco root system may be favored. The high precipitation along with pedogeneticallly young soils allow rapid saturation of the profile, which favors saturated water flow (Mandal et al., 2005).

At the beginning of the plant cycle, plant $\mathrm{N}$ demand increases, although the root system is then little developed (McCants \& Woltz, 1967), favoring nitrate leaching. Due to the losses at the beginning of the tobacco cycle, Whitty \& Gallaher (1995) recommend an additional application of $56 \mathrm{~kg} \mathrm{ha}^{-1} \mathrm{~N}$ before tobacco flowering when rainfall is intense and frequent, to compensate for leaching losses. This practice is also widespread among the local tobacco growers in rainy years.

Soil water infiltration was greater under NT and similar under CT and MT (Figure 3). NT was most 


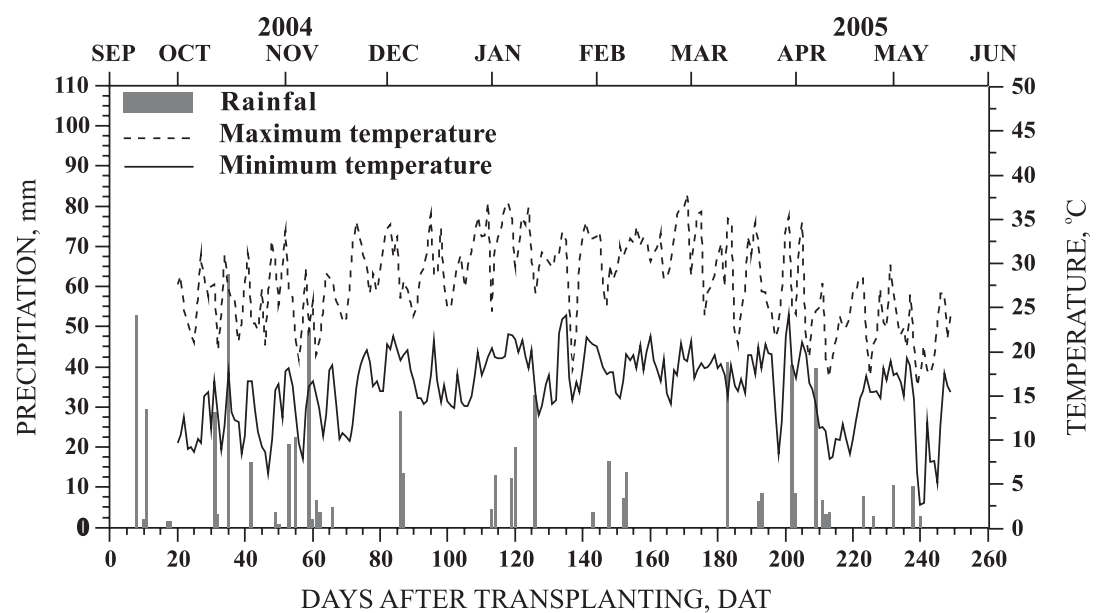

Figure 2. Rainfall and air temperature during the evaluation period.

efficient in reducing runoff water losses (Pellegrini, 2006), increasing rainfall water infiltration up to 35 DAT, mainly during the most intense rains at the beginning of crop establishment. This can be explained by the surface mulch, which prevents surface sealing and increases the tortuosity of the water flow and pore continuity under NT (Guadagnim et al., 2005), increasing soil water infiltration. Nevertheless, with time, the difference in the amount of infiltrated water among the management systems tended to decrease. Possibly, the decomposition of oat straw reduced the protective soil cover in $\mathrm{NT}$, and the lower rainfall intensity (Pellegrini, 2006) resulted in lower infiltration rates in NT.

The ridge for tobacco may also act as a water drainage channel. In minimum tillage, the presence of partially incorporated mulch in the planting row can reduce water runoff speed and allow greater water infiltration. Nevertheless, this effect was not detected in the experiment, possibly due to the small plot size.

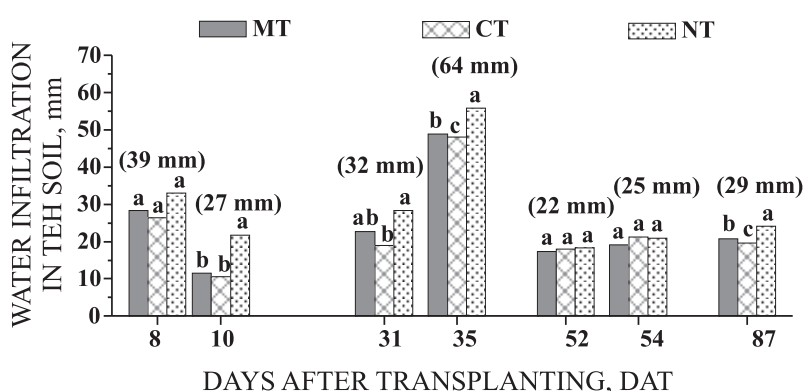

Figure 3. Water infiltration into the management systems during some rainfalls. Values in brackets represent the rainfall during the sampling period. Means followed by the same letters in the columns did not differ by the LSD test at $5 \%$.
Variation in the number and frequency of samplings (Figure 4) may be attributed to soi hydraulic changes caused by the management systems and rain distribution. In the beginning, when the rains were more frequent, soil maintained moisture was higher (Pellegrini, 2006) and the number of samplings greater, regardless of the management system. After this period (60 to 120 DAT), the soil solution could not be sampled (Tables 2 and 3), since soil moisture was low due to low rain frequency and high evapotranspiration demand caused by the phase of intense tobacco plant growth and high temperatures (Figure 1). New solution samplings during the tobacco cycle were only possible 126 DAT. After that, the soil solution was sampled 183, 203, 223, and 238 days after tobacco transplanting, which was already in the initial phase of the subsequent maize. In this period, the low temperatures reduced evapotranspiration and frequent rainfall maintained of a higher soil water content.

The $\mathrm{N}$ concentration in the soil solution was variable over the course of time among the management
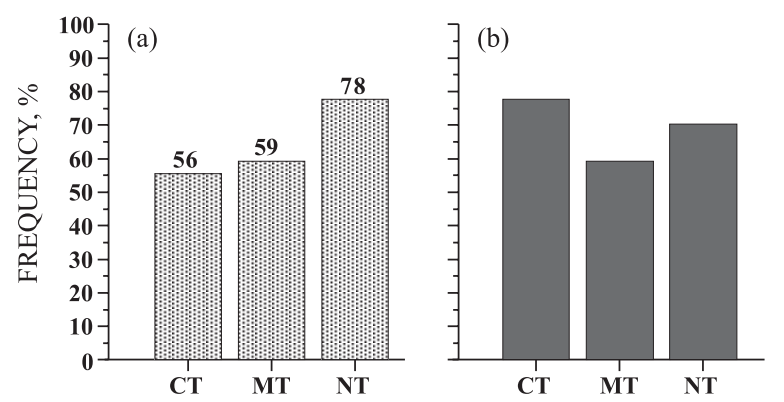

Figure 4. Frequency of soil solution sampling at depths of 0.15 (a) and $0.30 \mathrm{~m} \mathrm{(b)}$ in the soil management systems for tobacco implantation. 
Table 2. $\mathrm{N}$-nitrate and $\mathrm{N}$-ammonium concentrations in the tobacco root zone

\begin{tabular}{|c|c|c|c|c|}
\hline \multirow{2}{*}{ DAT } & \multicolumn{3}{|c|}{ Soil management } & \multirow{2}{*}{ CV } \\
\hline & CT & MT & NT & \\
\hline & $-\mathrm{N}$ & $\mathrm{NO}_{3}^{-}(\mathrm{mg} \mathrm{I}$ & 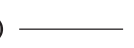 & $\%$ \\
\hline 12 & $15.79 \mathrm{a}$ & $39.50 \mathrm{a}$ & $56.49 \mathrm{a}$ & 43.26 \\
\hline 21 & $73.32 \mathrm{a}$ & $138.83 \mathrm{a}$ & $82.52 \mathrm{a}$ & 39.96 \\
\hline 34 & $129.47 \mathrm{a}$ & $226.20 \mathrm{a}$ & $111.87 \mathrm{a}$ & 37.85 \\
\hline 40 & 77.85 & 165.18 & 56.30 & - \\
\hline 129 & * & * & 26.62 & - \\
\hline 185 & $69.06 \mathrm{a}$ & $46.88 \mathrm{a}$ & $37.15 \mathrm{a}$ & 87.26 \\
\hline 205 & $41.13 \mathrm{a}$ & $37.68 \mathrm{a}$ & $27.40 \mathrm{a}$ & 45.31 \\
\hline 223 & $172.98 \mathrm{a}$ & $64.95 \mathrm{a}$ & $23.38 \mathrm{a}$ & 66.79 \\
\hline \multirow[t]{2}{*}{241} & 98.10 & 26.24 & 21.51 & - \\
\hline & \multicolumn{3}{|c|}{$\mathrm{N}-\mathrm{NH}_{4}^{+}\left(\mathrm{mg} \mathrm{L}^{-1}\right)$} & \\
\hline 12 & $6.59 \mathrm{a}$ & $4.52 \mathrm{a}$ & $8.99 \mathrm{a}$ & 57.0 \\
\hline 21 & $4.02 \mathrm{a}$ & $6.92 \mathrm{a}$ & $6.26 \mathrm{a}$ & 6.24 \\
\hline 34 & $4.87 \mathrm{a}$ & $7.87 \mathrm{a}$ & $4.06 \mathrm{a}$ & 66.85 \\
\hline 40 & $7.06 \mathrm{a}$ & $4.41 \mathrm{a}$ & $3.25 \mathrm{a}$ & - \\
\hline 129 & * & * & 6.35 & - \\
\hline 185 & $2.37 \mathrm{a}$ & $2.12 \mathrm{a}$ & $2.44 \mathrm{a}$ & 48.21 \\
\hline 205 & $6.71 \mathrm{a}$ & $3.88 \mathrm{a}$ & $3.58 \mathrm{a}$ & 56.43 \\
\hline 223 & $1.30 \mathrm{a}$ & $1.11 \mathrm{a}$ & $1.57 \mathrm{a}$ & 66.79 \\
\hline 241 & $113 \mathrm{a}$ & $212 \mathrm{a}$ & $0.69 \mathrm{a}$ & - \\
\hline
\end{tabular}

Means followed by the same letter in a row did not differ by the LSD test at $5 \%$. ${ }^{*}$ Periods without sampling. CT: conventional tillage, MT: minimum tillage and NT: no-tillage. CV: coefficient of variation. DAT: days after transplanting.

systems and depths evaluated, but the differences between the management systems were not statistically significant due to the high coefficient of variation of this parameter (Tables 2 and 3). The concentration of $\mathrm{N}\left(\mathrm{N}-\mathrm{NH}_{4}{ }^{+}\right.$and $\left.\mathrm{N}-\mathrm{NO}_{3}{ }^{-}\right)$in the soil solution was highest at the beginning of monitoring, after the application of base fertilization. The high ammonium content in the beginning was the result of base fertilization, where $\mathrm{N}$ is applied in ammoniacal form. This period was characterized by frequent rainfalls (Figure 2), resulting in a greater quantity of water in the soil (Pellegrini, 2006), which permitted solution sampling and may also have caused greater nitrate losses through leaching.

Ammonium concentration $\left(\mathrm{N}-\mathrm{NH}_{4}^{+}\right)$decreased over time in all management systems (Tables 2 and 3). This reduction may have resulted from the nitrification process and the uptake of part of the ammonium by the roots of the growing plants. In the soil, nitrification is a rapid process and leads to a significant increase in nitrate concentration (Paravasivam et al., 2000). The ammonium concentration was highest in the first 40 days after tobacco transplanting (DAT). The $\mathrm{N}$ detected in soil solution in this period was derived mainly from starter fertilization applied at planting, since the low organic matter content in the soil of the area $(1.15 \%)$ (Pellegrini, 2006) represents a poor $\mathrm{N}$ source for mineralization. The solution in no-tillage was only sampled 125 DAT, possibly due to the better water storage capacity in this management system.
There was a reduction in the nitrate concentration in the soil solution over time in all treatments, which may be attributed to $\mathrm{N}$ uptake from the soil solution by the growing crop, microbial immobilization and also to losses through runoff, denitrification and leaching. The solubilized nutrients remain in equilibrium between the solution and the soil solid phase. To the extent that the nutrients are removed from the solution by root uptake or loss, a new fraction of nutrients from the solid phase is made available, maintaining the balance. Nevertheless, the free form of nitrate predominates in the soil solution and its movement occurs through mass flow, following the soil water flow. For the study conditions, the predominance of coarse fractions in the soil reduced the formation of capillary pores and the macropores were predominant (Pellegrini, 2006; Kaiser, 2006) preventing the occurrence of upward flow and leading to predominance of downward water flow in the soil. The difference observed in nitrate concentrations between samplings may be attributed to the variation in the soil water content and to the hydraulic conductivity gradient, since after the solution is extracted around the cup, a potential gradient is formed, causing the solution from more distant points migrate to this region, to equalize soil water potential (Grossmann \& Udluft, 1991).

The tobacco $\mathrm{N}$ demand and uptake is highest in the first 50 DAT (McCants \& Woltz, 1967). For the experimental conditions, the low addition of crop

Table 3. N-nitrate and N-ammonium concentration below the tobacco root zone

\begin{tabular}{|c|c|c|c|c|}
\hline \multirow{2}{*}{ DAT } & \multicolumn{3}{|c|}{ Soil management } & \multirow{2}{*}{$\mathrm{CV}$} \\
\hline & CT & MT & NT & \\
\hline & $\longrightarrow$ & $\mathrm{NO}_{3}^{-}(\mathrm{mg}$ & & $\%$ \\
\hline 12 & $28.40 \mathrm{a}$ & $142.17 \mathrm{a}$ & $67.14 \mathrm{a}$ & 54.12 \\
\hline 21 & $65.85 \mathrm{a}$ & $145.41 \mathrm{a}$ & $58.75 \mathrm{a}$ & 35.18 \\
\hline 34 & $40.70 \mathrm{a}$ & $141.47 \mathrm{a}$ & $81.67 \mathrm{a}$ & 49.62 \\
\hline 40 & $119.28 \mathrm{a}$ & $153.92 \mathrm{a}$ & $62.49 \mathrm{a}$ & 31.66 \\
\hline 129 & $*$ & * & 7.83 & - \\
\hline 185 & 56.73 & * & 32.19 & - \\
\hline 205 & $45.78 \mathrm{a}$ & $52.51 \mathrm{a}$ & $17.75 \mathrm{a}$ & 34.96 \\
\hline 223 & $48.28 \mathrm{a}$ & $35.80 \mathrm{a}$ & $14.91 \mathrm{a}$ & 43.23 \\
\hline \multirow[t]{2}{*}{241} & $52.29 \mathrm{a}$ & $47.53 \mathrm{a}$ & $11.15 \mathrm{a}$ & 58.42 \\
\hline & -1 & $\mathrm{NH}_{4}^{+}(\mathrm{mg}$ & & \\
\hline 12 & $7.41 \mathrm{a}$ & $6.32 \mathrm{a}$ & $9.39 \mathrm{a}$ & 61.1 \\
\hline $\begin{array}{l}12 \\
21\end{array}$ & $8.10 \mathrm{a}$ & $9.51 \mathrm{a}$ & $6.85 \mathrm{a}$ & 74.35 \\
\hline $\begin{array}{l}21 \\
34\end{array}$ & $4.94 \mathrm{a}$ & $10.35 \mathrm{a}$ & $7.80 \mathrm{a}$ & 21.47 \\
\hline 40 & $3.67 \mathrm{a}$ & $4.69 \mathrm{a}$ & $3.95 \mathrm{a}$ & 51.25 \\
\hline 129 & $*$ & * & * & - \\
\hline 185 & 3.11 & * & 2.40 & \\
\hline 205 & $4.28 \mathrm{a}$ & $4.94 \mathrm{a}$ & $3.91 \mathrm{a}$ & 12.03 \\
\hline 223 & $1.60 \mathrm{a}$ & $1.56 \mathrm{a}$ & $1.39 \mathrm{a}$ & 43.23 \\
\hline 241 & $0.78 \mathrm{a}$ & $2.79 \mathrm{a}$ & $4.07 \mathrm{a}$ & 125.03 \\
\hline
\end{tabular}

Means followed by the same letter in a row did not differ by the LSD test at $5 \%$. * Periods without sampling. CT: conventional tillage, MT: minimum tillage and NT: no-tillage. $\mathrm{CV}$ : coefficient of variation. DAT: days after transplanting. 
residues, soil tillage and high porosity (Pellegrini, 2006) did not favor denitrification and, thus, leaching seems to be the main destination of the nitrate not used by the crop.

Highest nitrate concentrations were verified between 20 and 40 DAT under MT, at a depth of $0.15 \mathrm{~m}$ (Tables 2 and 3 ). In part, this may be attributed to the natural variation of the microrelief and the hydraulic properties of the soil of the area, since the great quantity of coarse fractions and stoniness have a significant influence on pore distribution and continuity and thus affect water infiltration and retention (Kaiser, 2006). The tortuosity of the water flow along the planting ridges of minimum tillage may have favored water infiltration in the soil, increasing the nitrate concentration in the soil solution below the root zone. In conventional tillage, the absence of mulch on the surface and planting ridge allowed surface sealing and rapid rainwater runoff and, consequently, infiltration was not promoted.

In tobacco management systems, Laird (2003) found greater $\mathrm{N}-\mathrm{NO}_{3}{ }^{-}$total loss under $\mathrm{NT}$ and $\mathrm{MT}$, since the amount of percolated water was $68 \%$ higher under MT and $167 \%$ higher under NT than under CT. On the other hand, NT and MT were more efficient in reducing $\mathrm{N}$ losses through surface runoff. Pellegrini (2006) also observed lower nutrient losses through runoff under NT and MT than under CT. Nevertheless, in this study, the quantity of infiltrated water under NT was not very different, and great water losses through internal drainage could not be attributed to the NT system, since soil density and porosity were similar in the management systems (Pellegrini, 2006). Randall \& Mulla (2001) observed that soil management did not affect nitrate losses through leaching, even though the drained water volume in NT was greater than in CT.

In conventional tillage and minimum tillage, fertilizers are incorporated to a greater depth and, thus, until the crop establishes its root system and can exploit the soil, part of the nitrate may already have reached deeper layers and remains beyond reach of the roots. In addition, incorporation increases the contact area of fertilizer with the soil, facilitating solubilization. For instance, Sangoi et al. (2003) verified greater nitrate leaching when the fertilizer was incorporated in the soil. In part, this may have been responsible for the higher nitrogen concentration at the beginning of crop establishment. In NT, fertilizers were applied near the root zone and, under these conditions, their solubilization and nitrate leaching may be minimized. Nitrate concentrations were lowest throughout the evaluation period under NT and, in spite of facilitating water infiltration and flow in the soil for being a conservationist system, its potential for groundwater contamination was lower.

In all management systems, nitrate concentration in the soil solution at levels below $50 \mathrm{mg} \mathrm{L}^{-1}$ were most frequent (Figure 5), with lowest concentrations under NT. Nitrate concentration was highest in the soil solution until 40 DAT and in the mean of both sampled layers under MT (Tables 2 and 3). In this treatment, a greater frequency of high nitrate levels was also verified, especially below the root zone (Figure 5). In the CT, the mean concentration was intermediate in relation to the other management systems, but presented greater frequency of high nitrate levels compared to NT, mainly in the root zone.

The nitrate concentrations measured below the tobacco root zone were high compared with other results in the literature, in spite of the great variation in nitrate concentration observed among treatments in time and space. The nitrate concentrations reported for tobacco in numerous field samplings exceed the natural concentrations found in forests and native fields (Williams, 1999). Grignani \& Zavattaro (2000) reported concentrations from 1 to $150 \mathrm{mg} \mathrm{L}^{-1} \mathrm{~N}_{-} \mathrm{NO}_{3}^{-}$ in crop-livestock integration systems with corn and barley production, where the mean concentration was greater in the most intensive systems and during the winter. Stenberg (1999) found concentrations from 5 to $30 \mathrm{mg} \mathrm{L}^{-1} \mathrm{~N}_{-} \mathrm{NO}_{3}{ }^{-}$in the soil solution sampled by tension lysimeters at 0.6 and $0.9 \mathrm{~m}$ depth. The nitrate contents detected in this study exceeded the mean concentrations observed by Oliveira et al. (2001) in the root zone of sugar cane $\left(14.5 \mathrm{mg} \mathrm{L}^{-1}\right)$ and below it

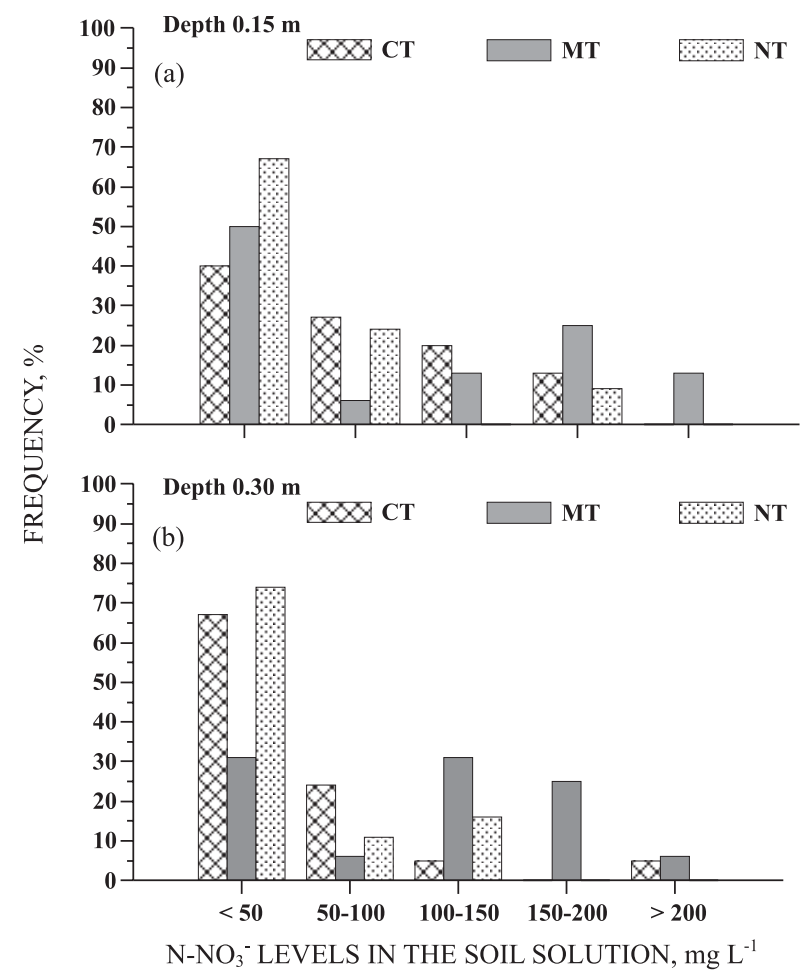

Figure 5. Frequency of nitrate concentration in the soil solution in the root zone (a) and below the root zone (b) of tobacco. 
(15 mg L-1), after an application of $190 \mathrm{~kg} \mathrm{ha}^{-1} \mathrm{~N}$. Pérez et al. (2003) found maximum concentrations of $60 \mathrm{mg} \mathrm{L}^{-1} \mathrm{~N}^{-\mathrm{NO}_{3}}{ }^{-}$in areas cultivated with potato and oat. Costa et al. (2002) reported values of more than $10 \mathrm{mg} \mathrm{L}^{-1} \mathrm{~N}^{-\mathrm{NO}_{3}}{ }^{-}$in $36 \%$ of the water sources in regions with intensive potato and corn production systems in Argentina. These authors stated that the concentrations in the cultivated areas were highest after $\mathrm{N}$ fertilization and periods of high rainfall, resulting in increased nitrate contents in the water table and river waters of the regions.

The method of porous cup lysimeters is promising for sampling the soil solution as an indicator of nitrate water contamination. However the device may underestimate the true solute concentrations, since the tension can only be applied and maintained under high soil moisture conditions (Reichardt et al., 1979). Tension was therefore only applied after the rain and, under these conditions, great part of the water flow in the soil had already occurred, due to the high porosity and stoniness of this soil. Thus, it is not possible to sample the drained solution due to the preferential flow that occurs in the macropores and soil voids, as commonly found in shallow soils with a high degree of stoniness. As a consequence, the concentration may be underestimated for the conditions of this study, since the physical properties of this soil are favorable for the downward flow, and the fertilizers applied to tobacco may represent an even greater risk for diffuse groundwater contamination than pointed out here.

Fertilization applied at transplanting of tobacco seedlings represents the main source of mineral $\mathrm{N}$ in the soil solution. When nitrate is leached below the root zone, the nutrient may turn into a pollutant and become a diffuse source of groundwater contamination (Costa et al., 2002). Therefore, the high doses of $\mathrm{N}$ fertilizers used for tobacco may impair the groundwater quality over time in these tobacco regions, as already observed by Gonçalves (2003) and Kaiser (2006), in some springs of this watershed. The use of cover plants as N source (Aita et al., 2004) for tobacco could reduce nitrate concentrations in the soil solution, minimizing the potential for water contamination. Nevertheless, future studies are necessary to confirm this hypothesis for tobacco cultivation conditions.

\section{CONCLUSIONS}

1. The high nitrate $\left(\mathrm{N}^{-} \mathrm{NO}_{3}{ }^{-}\right)$concentrations found in the soil solution at the beginning of the crop cycle and the content remaining after the period of high crop demand represent a contamination risk for groundwater.
2. Nitrate concentrations in the soil solution were highest after the application of base fertilization.

3. Nitrate concentrations in the soil solution during the tobacco cycle were highest under minimum tillage, whereas the difference to conventional tillage and notillage was statistically not significant.

\section{LITERATURE CITED}

ADDISCOTT, T.M. \& BENJAMIN, N. Nitrate and human health. Soil Use Manag., 20:98-104, 2004.

AITA, C.; GIACOMINI, S.J.; HÜBNER, P.A.; CHIAPINOTTO, I.C. \& FRIES, M.R. Consorciação de plantas de cobertura antecedendo o milho em plantio direto. I - Dinâmica do nitrogênio no solo. R. Bras. Ci. Solo, 28:739-749, 2004.

ALCÂNTARA, M.A.K. \& CAMARGO, O.A. Adsorção de nitrato em solos com cargas variáveis. Pesq. Agropec. Bras., 40:369-376, 2005.

BECKER, A.G.; MORAES, B.S.; MENEZES, C.C.; LORO, V.L.; SANTOS, D.R.; REICHERT, J.M. \& BALDISSEROTTO, B. Pesticide contamination of water alters the metabolism of juvenile silver Cat fish, Rhamdia quelen. Ecotoxitol. Environ. Safety, 72:1734-1739, 2009.

COSTA, J.L.; MASSONE, H.; MARTINEZ, D.; VIDAL, C.M. \& BEDMAR, F. Nitrate contamination of a rural aquifer and accumulation in the unsaturated zone. Agric. Water Manag., 57:33-47, 2002.

DALMOLIN, R.S.D.; PEDRON, F.A.; AZEVEDO, A.C. \& ZAGO, A. Levantamento semidetalhado de solos da microbacia do Arroio Lino- Município de Agudo-RS. Santa Maria, 2004. 86p.

EMPRESA BRASILEIRA DE PESQUISA AGROPECUÁRIA EMBRAPA. Centro Nacional de Pesquisa de Solos. Sistema brasileiro de classificação de solos. Brasília, 1999. $412 \mathrm{p}$.

GONÇALVES, C.S. Qualidade de águas superficiais na microbacia hidrográfica do Arroio Lino - Nova Boêmia Agudo - RS. Santa Maria, Universidade Federal de Santa Maria, 2003. 104p. (Tese de Mestrado)

GRIGNANI, C. \& ZAVATTARO, L. A survey on actual agricultural practices and their effects on the mineral nitrogen concentration of the soil solution. Europ. J. Agron., 12:251-268, 2000.

GROSSMANN, J. \& UDLUFT, P. The extraction of soil water by the suction-cup method: A review. J. Soil Sci., 42:8393, 1991.

GUADAGNin, J.C.; BERTOL, I. \& CASSOL, P.C. Perdas de solo, água e nitrogênio por erosão hídrica em diferentes sistemas de manejo. R. Bras. Ci. Solo, 29:277-286, 2005.

HENDERSHOT, W.H. \& COURCHESNE, F. Comparison of soil solution chemistry in zero tension and ceramic-cup tension lysimeters. J. Soil Sci., 42:577-583, 1991. 
KAISER, D.R. Nitrato na solução do solo e na água de fontes para consumo humano numa microbacia hidrográfica produtora de fumo. Santa Maria, Universidade Federal de Santa Maria, 2006. 114p. (Tese de Mestrado)

LAIRD, M.K. Surface and groundwater quality impacts of conservation tillage practices on burley tobacco production systems in Southwest Virginia. Blacksburg, Virginia State University, 2003. 106p. (Tese de Mestrado)

MANDAL, U.K.; RAO, K.V.; MISHRA, P.K.; VITTAL, P.R.; SHARMA, K.L.; NARSIMLU, B. \& VENKANNA, K. Soil infiltration, runoff and sediment yield from a shallow soil with varied stone cover and intensity of rain. Europ. J. Soil Sci., 56:435-443, 2005.

MCCANTS, C.B. \& WOLTZ, W.G. Growth and mineral nutrition of tobacco. Adv. Agron., 19:211-265, 1967.

MERTEN, G.H. \& MINELLA, J.P. Qualidade da água em bacias hidrográficas rurais: Um desafio atual para a sobrevivência futura. Agroec. Desenv. Rural Sustentável, 3:33-38, 2002.

MINELLA, J.P.G.; MERTEN, G.H.; REICHERT, J.M \& RHEINHEIMER, D.S. Identificação e implicações para a conservação do solo das fontes de sedimentos em bacias hidrográficas. R. Bras. Ci. Solo, 31:1637-1646, 2007.

MORENO, J.A. Clima do Rio Grande do Sul. Porto Alegre, Secretaria da Agricultura, Diretoria de Terras e Colonização. Seç̧ão de Geografia, 1961. 46p.

OLIVEIRA, F.C.; MATTIAZZO, M.E.; MARCIANO, C.R \& MORAES, S.O. Lixiviação de nitrato em um Latossolo Amarelo distrófico tratado com lodo de esgoto e cultivado com cana-de-açucar. Sci. Agríc., 58:171-180, 2001.

PARAVASIVAM, S.; ALVA, A.K. \& FARES, A. Transformation and transport of nitrogen forms in a Sandy Entisol following a heavy loading of ammonium nitrate solution: Field measurements and model simulations. J. Soil Contam., 9:65-86, 2000.

PELLEGRINI, A. Sistemas de cultivo da cultura do fumo com ênfase às práticas de manejo e conservação do solo. Santa Maria, Universidade Federal de Santa Maria, 2006. 88p. (Tese de Mestrado)

PELLEGRINI, J.B.R. Fósforo na água e no sedimento na Microbacia Hidrográfica do Arroio Lino - Agudo- RS. Santa Maria, Universidade Federal de Santa Maria, 2005. 98p. (Tese de Mestrado)

PÉREZ, J.M.S.; ANTIGUEDAD, I.; ARRATE, I.; GARCIA, C. \& MORELL, I. The influence of nitrate leaching through unsaturated soil on groundwater pollution in an agricultural area of the Basque Country: A case study. Sci. Total Environ., 317:173-187, 2003.

RANDALL, G.W. \& MULLA, D.J. Nitrate nitrogen in surface waters as influenced by climatic conditions and agricultural practices. J. Environ. Qual., 30:337-344, 2001.
RAO, E.V.S.P. \& PUTTANNA, K. Nitrates, agriculture and environment. Current Sci., 79:1163-1168, 2000.

REICHARDT, K.; LIBARDI, P.L \& VICTORIA, R.L. Dinâmica do nitrogênio num solo cultivado com milho. R. Bras. Ci. Solo, 3:17-20, 1979.

RHEINHEIMER, D.S. Caracterização física, química e biológica dos solos na microbacia hidrográfica do Arroio Lino, Nova Boêmia, Agudo - RS. Santa Maria, 2003. p.7-18. (Relatório Técnico)

RIO GRANDE DO SUL - Secretaria da Coordenação e Planejamento do Rio Grande do Sul. Atlas Socio econômico do RS. 2003. Available at:http:// www.scp.rs.gov.br/atlas/atlas.asp?menu=266 Accessed on: Jan. 15, 2006.

SANGOI, L.; ERNANI, P.R.; LECH, V.A. \& RAMPAZZO, C. Lixiviação de nitrogênio afetada pela forma de aplicação da uréia e manejo dos restos culturais da aveia em dois solos com textura contrastantes. Ci. Rural, 33:65-70, 2003.

SCHERER, H.W.; MACKOWN, C.T. \& LEGGETT, J.E. Ammonium uptake interactions in tobacco seedlings. J. Exper. Bot., 35:1060-1070, 1984.

SIFOLA, M.I. \& POSTIGLIONE, L. The effect of nitrogen fertilization on nitrogen use efficiency of irrigated and non- irrigated tobacco. Plant Soil, 252:313-323, 2003.

STENBERG, M. Soil mineral nitrogen and nitrate leaching losses in soil tillage systems combined with a catch crop. Soil Till. Res., 50:115-125, 1999.

STRECK, E.V.; KÄMPF, N.; DALMOLIN, R.S.D.; KLAMBT, E.; NASCIMENTO, P.C.; SCHNEIDER, P.; GIASSON, E. \& PINTO, L.F.S. Solos do Rio Grande do Sul. Porto Alegre, Emater/RS, 2008. 222p.

TEDESCO, M.J.; WOLKWEISS, S.J. \& BOHNEN, U. Análise de solo, plantas e outros materiais. 2.ed. Porto Alegre, Universidade Federal do Rio Grande do Sul, 1995. 174p. (Boletim Técnico, 5)

WEBSTER, C.P. SHEPHERD, M.A.; GOULDING, K.W.T. \& LORD, E. Comparisons of methods for measuring the leaching of mineral nitrogen from arable land. J. Soil Sci., 44:49-62, 1993.

WILLIAMS, T.M. Nitrate leaching from intensive fiber production on abandoned agricultural land. For. Ecol. Manag., 122:41-49, 1999.

WHITTY, E.B. \& GALLAHER, R.N. Supplemental nitrogen fertilizer for no-tillage tobacco following simulated excessive rainfall. University of Florida, Institute of Food and Agricultural Science, 1995. Available at: <http:// www.ag.auburn.edu/aux/nsdl/sctcsa/Proceedings/ Whitty>. Accessed on: July 10, 2005.

ZHANG, H.; JENNINGS, A.; BARLOW, P.W. \& FORDE, B.G. Dual pathways for regulation of root branching by nitrate. Plant Biol., 96:6529-6534, 1999. 
